\title{
Interpretative Phenomenological Analysis: Kebahagiaan di Tempat Kerja pada Karyawan di Divisi Sumber Daya Manusia
}

\section{Interpretative Phenomenological Analysis: Happiness at Work for Employees in the Human Resource Development Division}

\author{
Desi Wulandri ${ }^{*}$, Megawati Batubara ${ }^{1}$ \\ ${ }^{1}$ Fakultas Psikologi, Universitas Padjadjaran \\ *desi20003@mail.unpad.ac.id
}

\begin{abstract}
Abstrak
Penelitian ini bertujuan untuk memahami bagaimana gambaran HAW pada karyawan yang bekerja dibidang sumber daya manusia atau dikenal juga dengan HRD (human resource development). HRD memainkan peranan penting dalam mendukung agenda perusahaan sehingga penting bagi divisi HRD yang bertugas untuk mengelola seluruh sumber daya manusia di dalam perusahaan supaya berjalan secara efektif dan efisien. Metode pada penelitian ini adalah metode kualitatif fenomenologis. Tiga partisipan dalam penelitian ini direkrut secara purposif diwawancarai secara semi-terstruktur. Digunakan empat kriteria kualitas sebagai wujud kredibilitas penelitian. Transkrip wawancara dianalisis secara kualitatif menggunakan pendekatan Interpretative Phenomenological Analysis (IPA), IPA mengeksplorasi secara rinci proses yang dilalui partisipan untuk memahami pengalaman mereka sendiri. Analisis data memunculkan lima tema superordinat, yaitu (1) penilaian terhadap perusahaan, (2) kepuasan terhadap perusahaan dan lingkungan, (3) dedikasi atau rasa kepemilikan perusahaan, (4) kesulitan yang dihadapi, (5) ketahanan. Temuan penelitian ini menunjukkan setiap partisipan memiliki kesulitan dan tantangan yang dihadapi tetapi bagaimana partisipan tetap dapat menjalani aktivitas walaupun ada kesulitan dan tantangan yang dihadapi sehingga individu dapat berkembang dengan mengatasi emosi negatif serta memberikan kemampuan terbaiknya untuk membantu dirinya saat menghadapi kesulitan dan tantangan.
\end{abstract}

Kata kunci: interpretative phenomenological analysis, IPA, human resources development, HRD, happiness at work.

\begin{abstract}
This study aims to understand how happiness at work portrays for employees who work in the field of human resources development (HRD). HRD plays an important role in supporting the company's agenda so it is important for the HRD division to manage all human resources in the company so that it runs effectively and efficiently. The method in this study is a phenomenological qualitative method. Three participants in this study were recruited purposively were interviewed using a semi-structured interview. Four quality criteria are used as a form of research credibility. Transcripts were analyzed qualitatively using the Interpretative Phenomenological Analysis (IPA), IPA explores in detail the processes that participants go through to understand their own experiences. Data analysis raises five superordinate themes: (1) employee assessment of the company, (2) satisfaction with the company and the environment, (3) dedication or a sense of company ownership, (4) difficulties faced, (5) resilience. The findings of this study indicate that each participant has difficulties and challenges faced, but how can participants continue to carry out activities despite the difficulties and challenges they face so that individuals can develop by overcoming negative emotions and giving their best ability to help themselves when facing difficulties and challenges.
\end{abstract}

Keywords: interpretative phenomenological analysis, IPA, human resources development, HRD, happiness at work. 


\section{Pendahuluan}

Sumber Daya Manusia (SDM) merupakan aset terpenting pada suatu organisasi. Sumber daya manusia atau biasa dikenal dalam Bahasa Inggris adalah human resource. Untuk memiliki human resource yang berkualitas dibutuhkan pengelolaan yang baik guna menunjang pengembangan human resource yang baik. Pengembangan human resource atau Human Resource Development (HRD) merupakan pengembangan sumber daya manusia dengan menggabungkan pengembangan pelatihan dan karir untuk meningkatkan efektivitas individu, kelompok, dan organisasi (Irmawati, 2015). HRD adalah proses pengembangan dan menunjukkan keahlian individu melalui pengembangan organisasi dan pelatihan dan pengembangan kepribadian guna meningkatkan kinerja individu (Swanson \& Holton, 2001). HRD merupakan aset yang dinamis, berharga dan dapat dikembangkan sesuai dengan tujuan sehingga dapat mendukung kesuksesan organisasi (Parameswari \& Yugandhar, 2015; Putri, 2013). HRD diidentifikasikan memainkan peranan penting dalam mendukung agenda tanggung jawab sosial perusahaan (Jang \& Ardichvili, 2020). HRD didasari pada keyakinan bahwa organisasi adalah entitas buatan manusia yang mengandalkan keahlian manusia untuk menetapkan dan mencapai tujuan mereka serta seorang HRD profesional adalah pendukung individu dan kelompok, proses kerja dan integritas organisasi (Hassan, 2007).

Karyawan di divisi HRD bertugas untuk mengelola human resource dalam perusahaan sehingga perusahaan dapat berjalan baik guna mencapai tujuan perusahaan. HRD adalah proses mengoptimalkan produksi dan pemanfaatan tenaga kerja (Hamad \& Mahidy, 2018). Penting untuk mengelola sumber daya manusia sehingga dapat bersaing dan mencapai keunggulan yang kompetitif (Kasmawati, 2017). Kualitas sumber daya manusia yang baik akan menunjang keberhasilan instansi atau perusahaan tersebut. Maka dari itu divisi HRD pada sebuah organisasi, instansi atau perusahaan sering disebut sebagai jantung dan kunci kesuksesan suatu perusahaan. Divisi HRD memainkan peranan penting karena HRD sendiri dianggap memainkan peranan pada beberapa bidang yaitu; keragaman, keadilan, penyetaraan, keterikatan instansi, keseimbangan kehidupan kerja, pertumbuhan dan perkembangan jangka panjang karyawan, manajemen kinerja, etika bisnis, budaya etika, dan meningkatkan kesadaran akan tanggung jawab sosial perusahaan (Jang \& Ardichvili, 2020).

Pemenuhan HRD dengan kompetensi yang baik dan sesuai dengan tujuan perusahaan merupakan tugas dari karyawan di divisi HRD untuk dapat menerapkan semboyan right people, right place, right time' karyawan divisi HRD memiliki proses perencanaan yang sistematis yang terangkum dalam tugas kerja HRD. Divisi HRD bertugas dalam pengembangan sumber daya manusia (HRD) untuk meningkatkan produktivitas karyawan, tugas divisi HRD antara lain; (1) melakukan persiapan dan seleksi tenaga kerja, (2) pengembangan dan evaluasi karyawan, (3) memberikan kompensasi dan proteksi pada karyawan, (4) pengelola hubungan antara manajemen dengan karyawan, (5) pelatihan, (6) manajemen pengembangan diri, (7) penilaian kerja (Irmawati, 2015). Setiap karyawan yang bekerja memiliki sasaran kerja atau beban kerja atau tuntutan kerja yang diberikan oleh atasan ataupun perusahaan. Tuntutan kerja adalah aspek fisik, psikis, sosial dan organisasi dari pekerjaan yang membutuhkan usaha fisik dan keterampilan, karena berkaitan dengan biaya psikis (psychological cost), tekanan kerja dan tuntutan emosional karyawan (Schaufeli \& Bakker, 2004).

Beban kerja yang berlebihan, hubungan dengan atasan atau rekan kerja yang buruk, gaji yang terlalu rendah, dan waktu kerja yang panjang dapat menimbulkan stres kerja (Interactive, 2012). Beban kerja atau tuntutan kerja memiliki pengaruh yang signifikan terhadap stres kerja yang dimediasi secara parsial oleh motivasi kerja (Ramadhani \& Etikariena, 2018). Stres kerja adalah kondisi dinamik individu dalam menghadapi tuntutan, kendala, atau peluang yang ingin dicapai (Robbins, 2006). National Institute for Occupational Safety and Health (NIOSH) mendefinisikan stres kerja sebagai respon fisik dan emosional yang berbahaya yang terjadi saat peran pekerjaan tidak sesuai dengan kemampuan, sumber daya, dan kebutuhan pekerja (The National Institute for Occupational Safety and Health (NIOSH), 1999).

Penting untuk dapat mengelola stres dalam bekerja sehingga individu tetap dapat menyelesaikan pekerjaannya. Individu membutuhkan adanya keseimbangan antara faktor-faktor yang berasal dari dalam maupun dari luar dirinya sehingga mampu meningkatkan produktivitas kerja (Fisher, 2010). Disamping emosi-emosi negatif individu adapula emosi positif. Karyawan yang memiliki sikap positif dapat memberikan kontribusi efektif pada perusahaan dalam mencapai tujuan. Perjalanan dimana individu dapat tumbuh berkembang dan disaat yang pula individu dapat mengatasi emosi 
negatif serta dapat tetap memberikan kemampuan terbaiknya pada perusahaan adalah happiness at work (Pryce-Jones, 2010).

Happiness at work merupakan sebuah konsep yang menaungi berbagai konsep seperti suasana hati dan emosi yang bersifat sementara hingga suasana hati dan emosi yang relatif stabil (Fisher, 2010). Fisher (2010) menjelaskan bahwa happiness merupakan bentuk dari suasana hati dan emosi yang menyenangkan, merasa well-being, dan sikap positif. Menurut Lutterbie dan J. Pryce-Jones (2013) happiness at work adalah sebuah pola pikir yang memungkinkan individu untuk memberikan kinerja yang maksimal dan memaksimalkan potensial yang dimiliki. Dilakukan dengan memperhatikan suka dan duka saat bekerja sendiri atau bersama orang lain. Pada suatu lingkungan happiness at work diibaratkan sebagai perekat yang mempertahankan dan memotivasi karyawan untuk menjadi karyawan berkualitas tinggi dimasa depan (Fisher, 2010). Pryce-Jones (2010) mengemukakan bahwa terdapat lima komponen penting dari happiness at work yaitu 5C, contribution, conviction, culture, commitment, dan confidence. 5C terangkum dalam tiga aspek happiness at work yaitu (1) pride, perasaan bangga menjadi bagian dari organisasi dan bangga atas pekerjaan yang dimiliki akan muncul atas pencapaian prestasi muncul melalui emosi secara tidak sadar; (2) trust, sumber sosial dan psikologikal yang akan membantu fokus dalam pekerjaan; dan (3) recognition, dikenal dan diakui orang lain atas pekerjaan yang telah dilakukan adalah imbalan yang berarti. Sedangkan Fisher (2010) menjelaskan ukuran happiness at work dapat dirangkum secara komprehensif pada tiga aspek yaitu, (1) engagement, keterikatan, keadaan emosional yang menyenangkan atau positif yang dihasilkan dari penilaian pekerjaan atau pengalaman kerja seseorang, (2) job satisfaction, sebuah keadaan emosional yang menyenangkan atau positif yang dihasilkan dari penilaian atau pengalaman kerja individu, dan (3) affective organizational commitment, perilaku dimana orang memberikan diri mereka atau mendedikasikan diri mereka pada pekerjaan mereka.

Happiness at work pada divisi HRD ini memiliki peranan penting dalam menjalankan misi perusahaan. Misi divisi HRD dan divisi organization development (OD) dalam organisasi selain untuk meningkatkan kinerja individu dan organisasi juga untuk meningkatkan kesejahteraan karyawan (Joo \& Lee, 2017). Joo \& Lee (2017) Divisi HRD dapat meningkatkan kebahagiaan karyawan tidak hanya dalam pekerjaan dan karir tetapi juga dalam kehidupan karyawan dengan meningkatkan persepsi dukungan organisasi dan mengembangkan psychological capital (self-efficacy, optimisme, hope, dan resilliency). Dimasa depan, divisi HRD membutuhkan kompetensi yang dapat memberikan strategi kompetitif bagi organisasi yang mana dapat memberikan dasar keberlangsungan proses dan sistem dalam mengintegrasikan bisnis organisasi (Sharma, 2012). Divisi HRD memainkan peran penting dalam membantu organisasi dan individu belajar dari pengalaman, berkembang, mengelola risiko, dan membangun budaya karir yang berkelanjutan (Park et al., 2021). Sebelum memberikan peran tersebut kepada individu dan organisasi, karyawan di divisi HRD perlu untuk memperhatikan dirinya terlebih dahulu agar dapat menampilkan kinerja yang optimal dalam menjalankan peranannya terhadap perusahaan.

Happiness mampu memberikan dampak positif dalam kehidupan dengan memiliki hubungan interpersonal yang baik, produktif, dan memiliki rencana hidup yang baik (Carr, 2004). Happiness membuat individu lebih produktif, kebahagiaan yang lebih rendah secara sistematis dikaitkan dengan produktivitas yang lebih rendah (Oswald et al., 2015). Kemudian happiness at work disebut sebagai suatu keadaan yang berkontribusi positif pada produktivitas suatu organisasi (Keyes et al., 2000). Happiness at work sangat penting bagi seluruh karyawan apalagi untuk divisi HRD yang bertugas untuk mengelola sumber daya manusia di dalam perusahaan untuk dapat berjalan secara efektif dan efisien. Kebahagiaan dalam bekerja menjadi penting dimana individu dapat bekerja dengan nyaman. Berdasarkan paparan diatas, peneliti memiliki pertanyaan penelitian yaitu bagaimana karyawan divisi HRD memaknai perjalanan bekerja menjadi karyawan HRD dan mengatasi emosi negatifnya. Penelitian ini bertujuan untuk mengetahui dan memahami gambaran happiness at work pada pengalaman karyawan yang bekerja di divisi HRD dalam bekerja dan mengatasi emosi negatif.

\section{Metode Penelitian}

Penelitian kualitatif ini menggunakan pendekatan interpretative phenomenological analysis (IPA). IPA berusaha untuk meneliti bagaimana individu memaknai pengalaman penting dalam hidupnya dalam latar alami (Smith, Flower \& Larkin, 2009). IPA adalah sebuah pendekatan induktif yang bertujuan untuk menangkap dan mengeksplorasi makna yang diberikan partisipan pada 
pengalaman mereka (Reid et al., 2005). Proses ini mencakup semua aspek refleksi diri dan mengacu pada cara IPA mengasumsikan bahwa partisipan berusaha menafsirkan pengalamannya menjadi beberapa bentuk yang dapat dimengerti oleh mereka (Brocki \& Wearden, 2006). Partisipan penelitian sebagai orang yang mengalami langsung. Partisipan adalah pakar tentang pengalaman mereka sendiri dan dapat menjelaskan pemahamannya kepada peneliti tentang pikiran, komitmen, dan perasaan mereka dengan menceritakan kisah mereka sendiri, dengan kata-kata mereka sendiri, dan sejelas mungkin (Brocki \& Wearden, 2006; Reid et al., 2005). Untuk penelitian ini, partisipan yang pengalaman hidupnya dieksplorasi adalah karyawan yang bekerja di divisi HRD.

Data atau informasi terkait pengalaman partisipan didapatkan melalui wawancara semiterstruktur. Peneliti mewawancarai partisipan menggunakan panduan wawancara yang berisi pertanyaan yang disusun berdasarkan konsep happiness at work oleh Fisher (2010). Terdiri dari pertanyaan utama "Bisa diceritakan pengalaman bekerja Anda di divisi HRD?" Kemudian pertanyaanpertanyaan lain menyusul setelah partisipan menceritakan pengalamannya. Partisipan diberikan kesempatan yang luas untuk bercerita mengenai pengalaman bekerjanya. Ketika ada jawaban yang perlu diperjelas, peneliti mengajukan pertanyaan susulan untuk diklarifikasi oleh partisipan. Saat melakukan wawancara, peneliti sebagai pewawancara menjaga diri untuk memerhatikan epoché (netralitas) dalam mengajukan pertanyaan. Proses wawancara berlangsung secara daring menggunakan media meeting online menimbang adanya peraturan pemerintah terkait pandemi COVID-19. Proses wawancara direkam atas persetujuan partisipan dan hasilnya ditranskripkan secara verbatim.

Partisipan pada penelitian ini direkrut secara purposif. Adapun kriteria partisipan yang direkrut adalah; (1) karyawan divisi sumber daya manusia atau divisi human resource development (HRD) atau sejenisnya, (2) sudah bekerja selama minimal enam bulan. Partisipan pada penelitian ini terdiri dari tiga partisipan dengan rentang usia 23 dan 24 tahun dan telah bekerja di divisi HRD antara 1 sampai 2 tahun. Jumlah sampel yang kecil tidak menjadi masalah selama analisis dilakukan secara rinci untuk mengupas perbedaan dan kemiripan pada sampel yang kecil itu (Matthews \& Ross, 2010).

Kualitas penelitian kualitatif dilakukan dengan beberapa kriteria yang dapat digunakan supaya validitas dapat ditegakkan menggunakan empat kriteria (Yardley, 2017), yaitu (1) sensitivitas pada konteks, (2) kelengkapan data, analisis, dan interpretasi, (3) refleksivitas peneliti, dan (4) signifikansi peneliti. Penelitian ini telah mendapatkan nomor etik penelitian dari Komisi Etik Penelitian Universitas Padjadjaran No. 1177/UN6.KEP/EC/2020.

\section{Hasil Penelitian}

Identitas semua partisipan disamarkan untuk alasan etis, semua partisipan bekerja di bagian human resource atau sumber daya manusia perusahaan. Fokus pekerjaan untuk partisipan 1 adalah sebagai talent acquisition, partisipan 2 sebagai rekruter, dan partisipan 3 sebagai tim training. Adapaun karakteristik partisipan dapat dilihat pada Tabel 1.

Tabel 1. Karakteristik partisipan

\begin{tabular}{|c|c|c|c|}
\hline & Partisipan 1 & Partisipan 2 & Partisipan 3 \\
\hline Usia & 23 tahun & 23 tahun & 24 tahun \\
\hline Lama kerja & 2 tahun & 1 tahun & 1 tahun \\
\hline $\begin{array}{l}\text { Divisi kerja di } \\
\text { perusahaan }\end{array}$ & $\begin{array}{c}\text { HR } \\
\text { (Human Recource) }\end{array}$ & $\begin{array}{c}\text { HR } \\
\text { (Human Recource) }\end{array}$ & $\begin{array}{c}\text { HR-GA } \\
\text { (Human Recource- } \\
\text { General Affair) }\end{array}$ \\
\hline $\begin{array}{l}\text { Fokus tanggung jawab } \\
\text { kerja }\end{array}$ & $\begin{array}{l}\text { talent acquisition, } \\
\text { rekruter sales }\end{array}$ & rekrutmen & $\begin{array}{c}\text { people development, } \\
\text { training }\end{array}$ \\
\hline Lama wawancara & 39 menit & 75 menit & 47 menit \\
\hline
\end{tabular}

Jawaban didapatkan dalam bentuk laporan pengalaman pribadi. Hasil analisis menunjukkan lima tema superordinat, yaitu (1) penilaian terhadap perusahaan, (2) kepuasan terhadap perusahaan dan lingkungan, (3) dedikasi atau rasa kepemilikan perusahaan, (4) kesulitan yang dihadapi, (5) ketahanan. Berikut ini adalah gelaran temuan untuk tema superordinat. Saat menyajikan ekstrak dari transkrip peneliti memperjelas konteks dengan menambahkan tiga notasi, yaitu "..." untuk jeda, "[...]" untuk bagian transkrip yang dihilangkan, dan “(...)" untuk penjelasan tambahan dari peneliti. 


\section{1) Penilaian terhadap perusahaan}

Ketiga partisipan memiliki penilaian yang baik pada perusahaannya. Terkait lokasi kantor sesuai dengan yang diinginkan sampai arti kantor atau perusahaan bagi partisipan. Hal ini mewakili keterlibatan afektif dan kognitif serta ketertarikan emosional yang menyenangkan yang dihasilkan dari penilaian pekerjaan atau pengalaman seseorang.

Partisipan 1 mengemukakan perasaan senang bergabung dengan perusahaan karena sudah familiar dengan budaya kerja dari perusahaan sebelumnya yang merupakan bagian dari perusahaan partisipan 1 sekarang. Partisipan 1 juga memiliki ketertarikan pada perusahaan. Partisipan 1 juga senang bekerja di perusahaannya karena ia memiliki rekan kerja yang supportive. Partisipan 1 mengungkapkan sebagai berikut,

"[...] sebenernya seneng banget, karena em sebenernya waktu itu em karena jadi company ku yang sekarang ini dulu tuh em partner dari company ku yang sebelumnya gitu. Jadi sebenernya aku udah, waktu kerja di G diperusahaan aku yang sebelumnya aku udah kurang lebih udah familiar gitu dengan $\mathrm{X}$ gitu, jadi udah pernah cari-cari tahu $\mathrm{X}$ itu seperti apa dan memang menarik dari awal tuh memang udah ada keinginan kayaknya oke nih gitu untuk aku bisa join, eh ternyata ketika melamar kebetulan memang jodohnya rezekinya di X gitu, jadi happy banget sih waktu tau dapet di X."

"[...] karena berhubung aku suka dengan perusahaannya dan em... orang-orangnya itu sangat supportive [...]"

Bagi partisipan 1 perusahaannya merupakan tempat bekerja yang dapat memberikan ruang untuk belajar dan menemukan hal-hal baru. Perusahaan sebagai sebuah kesempatan besar untuk partisipan 1 dapat mengembangkan diri.

"[...] jadi kantor itu gak cuma tempat kita untuk kerja gitu loh.. jadi juga tempat untuk kita nyari hal hal baru dan em kurang lebih company ku bisa memfasilitasi itu gitu"

"[...] tempat kerja yang bisa memberi aku ruang untuk belajar sih gitu.. em apa yah.. aku tuh mengartikan company ku yang sekarang itu lebih ke big opportunity untuk aku bisa bener-bener berkembang sih.. [...]”

Partisipan 2 menilai perusahaanya sebagai gerbang pembuka dan tempat pertama kali berpijak untuk karir partisipan. Bagi partisipan perusahaan sebagai tempat dibukakan jalan rezeki.

"[...] selain sebagai gerbang pembuka sih sebenernya.. [...]"

"[...] pokoknya ini tuh tempat aku berpijak pertama kali gitu buat jadi seorang rekruter atau bekerja di dunia profesional di karir aku lah gitu, tempat berpijak aku pertama tempat kayak.. aku bisa bilang sih dibukakan lah rezeki gitu aku disini gitu [...]”

Partisipan 2 mengungkapkan loyalitas, kekompakan, dan kebersamaan yang partisipan lalui dengan rekan kerja. Seperti aktivitas yang selalu dilakukan partisipan dengan rekan kerja seperti menggunakan pakaian dengan warna senada pada hari tertentu, kemudian juga memberikan sebuah kejutan ketika ada yang berulang tahun dan menjenguk ketika ada yang sakit serta momen-momen spesial yang terjadi seperti pernikahan dan melahirkan. Hal itu dilakukan kepada seluruh karyawan yang ada mulai dari supir perusahaan sampai office boy.

"yaa kompaknya sih sebenernya hampir sama sih kayak di perusahaan perusahaan lain, kayak misalkan kalo di divisi aku tuh kita punya baju.. bukan baju ya, kita tuh bener-bener kayak kompak kayak hari hari tertentu kita tuh pake baju kembar gitu loh, kayak hari Senin kita pake baju biru terus hari Rabu pake seragam, terus hari Kamis kita pake putih, terus hari Jum'at memang sekantor pake batik gitu kan. [...]"

[...] nah kita tuh kompak disitu, terus juga kalau misalkan ada yang ulang taun, ada yang apa.. misalkan kayak juga nikahan terus em.. ini.. apa namanya em lahiran gitu tuh kita tuh bener bener jengukin bareng gitu, even sampe OB itu OB yang masuk rumah sakit, kita ikut juga itu apa tuh namanya em jengukin bareng sampe ke rumah sakit juga, terus istilahnya... driver juga ada $[. .]$.

Partisipan 3 mengungkapkan penilaiannya terhadap perusahaan, ia senang dapat bekerja di perusahaan. Disamping karena perusahaan partisipan 3 merupakan perusahaan yang sudah partisipan incar, hal ini juga karena lokasi kantor yang dekat dari ruman sehingga kantor terasa seperti bukan tempat untuk bekerja. Partisipan juga merasa diayomi oleh para rekan kerjanya karena paling muda 
dari yang lain. Disamping rekan kerja saling membantu ketika ada kesulitan pada pekerjaan, partisipan pun berbagi cerita dari masalah pekerjaan sampai masalah pribadi.

"[..] terus aku sih seneng karena memang.. pertama memang itu salah satu perusahaan yang aku... e.. masukin list lah di perusahaan yang memang aku incer, terus yang kedua memang karena perusahaannya deket rumah, yaaa sekitar 15 sampai 30 menit tuh udah sampe gitu [...]"

"[...] jadi ya aku sampai sekarang menganggap bahwa kantor itu rumah kedua ku dengan.. dengan e... keluarga keluarga kecil ku di sana kayak gitu (tersenyum). Kalau untuk relasi sih aku so far baik, karena memang sebenernya juga aku paling kecil disana jadi aku sih ngerasanya aku cukup dimanja disana karena aku yang paling kecil, mereka banyak e.. ngayomin aku, ngebantu aku gitu, banyak denger denger cerita ku, keluh kesah ku kayak gitu, kayak gitu tuh mereka dengerin, mereka menghibur aku, mereka ngebantu aku misalkan untuk mencari solusi, gimana sih e... apa yang harus aku lakukan gitu ketika memang ada masalah gitu dan akuuu e.. sama mereka juga udah bukan bahas kerjaan aja, kita juga mulai banyak bahas kayak terkait kayak.. masalah masalah pribadi gitu juga itu kita bahas gitu [...]"

\section{2) Kepuasan terhadap perusahaan dan lingkungan}

Ketiga partisipan mengungkapkan perasaan senang akan pengalaman kerja yang didapat. Diwakili dengan penilaian kognitif tentang pekerjaan tersebut, hal ini terkait gaji, rekan kerja, atasan dan lingkungan kerja yang dihasilkan dari penilaian atau pengalaman kerja partisipan.

Partisipan 1 mengungkapkan kemanfaatan yang ia terima dari perusahaan seperti partisipan mendapatkan pelajaran baru yang sebelumnya belum didapatkan. Partisipan menyadari banyak yang dapat ia manfaatkan dari apa yang perusahaan berikan antara lain adalah kompetensi diri. Partisipan juga mengungkapkan bagaimana kebijakan atasan yang cukup transparan dan memberikan kesempatan baik untuk karyawan belajar sehingga memberikan kesempatan partisipan untuk berkembang.

"[...] sebenernya kalau di X tuh aku banyak dapet pelajaran pelajaran baru yang belum tentu aku bisa dapet di company lain [..]"

"[...] kalo untuk leader leader aku tuh orangnya sangat transparan, jadi ketika aku memang ada kesalahan dia pasti bilang biasanya, A buat next time nanti gini gini gini yaaa, A buat next time gini-gini ya. Jadi em apa ya itu juga salah satu hal yang menurut aku membuat aku bisa berkembang sih. [..]”

"[..] saat ini tuh menemukan banget kalau di company ku ini tuh sangat mendukung orang untuk berkembang gitu.....]"

Partisipan 2 mengungkapkan kemanfaatan yang dirasakan seperti banyak kesempatan yang diberikan oleh perusahaan, partisipan mendapatkan pelajaran dengan learning by doing. Hal itu dirasa sangat membantu partisipan mempelajari hal yang baru yang sebelumnya partisipan takuti, seperti wawancara atau interview. Partisipan bersyukur atas kesempatan yang ia dapatkan itu. Partisipan lega akan perbedaan usia antar rekan kerja yang tidak begitu jauh sehingga partisipan dapat merasa nyaman dan berbagi cerita mengenai pekerjaan.

"[..] walaupun emang di tempat aku tuh semua.. semua pembelajarannya tuh learning by doing, jadi ga ada tuh training training gitu dulu, [..] hari ke.. 3 atau ke 4 ya buat orang fresh graduate tuh bener bener udah... wawancara sendiri gitu udah wawancara sendiri udah wawancara sendiri.. ya masih diawasin sih sama supervisor ku cuman kita udah e.. istilahnya interview karyawannya sendiri gitu, habis itu juga udah presentasiin sendiri juga ke manager gitu gitu buat orang yang fresh graduate gitu ya.. terus jadi kayak banyak banget sih disini yang bisa aku pelajari disini gitu[..."

"[..] di kantor aku tuh enak sih karena itu sih tadi banyak banget yang bisa di ambil banyak banget yang bisa dipelajarin buat step awal gitu.. [..]"

"[..] bisa dapetin juga nih challenges kesempatan buat interview langsung gitu, interview terus gitu, nah itu sih paling paling, paling apa ya.. paling aku syukurin gitu.[..]"

"[..] enaknya karena masih muda juga jadi kita bisa banyak belajar juga sih dari mereka gitu, jadi mereka juga gak yang sen.. gak yang se... istilahnya sejauh itu kan gap yearnya [..]" 
Partisipan 3 mengungkapkan kemanfaatan dan kenyamanan yang ia terima dari perusahaannya. Partisipan 3 mengungkapkan banyaknya pelajaran baru yang ia dapatkan dari perusahaan. Partisipan 3 merasakan kenyaman untuk bekerja di perusahaannya karena rekan kerja yang saling membantu, kenyamanan yang diberikan oleh atasan dan kenyamanan akan fasilitas kantor yang diberikan. Partisipan cukup puas akan benefit yang ia terima karena sesuai dengan tanggung jawab pekerjaan yang ada.

"[..] banyak banget hal yang baru banget aku pelajarin terkait dunia OD organizational development atau PIO itu justru setelah aku kerja gitu, apa yang aku dapet di kuliah gitu hampir sama sekali gak kepake gitu terkait PIO, mungkin karena memang aku juga gak mendalami PIO ya waktu kuliah ya jadi clueless banget gitu, tapi di satu sisi aku jadi mau belajar gitu aku tuh jadi.. mau belajar, banyak belajar [..]"

"[..] semakin kesini akuuu justru malah semakin nyaman gitu di perusahaan ku, kenapa? Walaupun orang orangnya mungkin ada beberapa yang nyebelin ya, maksudnya diluar sini itu yang ku bilang itu tadi susah diajak koordinasi kooperatif segala macem tapi itu tuh banyak hal hal yang membuat kantor aku itu e.. membuat aku nyaman gitu disitu, yang pertama dan itu udah jadi nilai plus mutlak itu adalah deket rumah [..] maksudnya kayak ketika gua berangkat ke kantor gue tuh gak ngerasa kayak gue berangkat kantor gitu, gue tuh cuma ngerasa kayak gue yaudah gue lagi ke suatu tempat... tempat yang rutinitas gue e...[..]"

"[..] temen temen di unit aku itu orangnya baik baik banget, baik baik banget, supportive banget juga aku tuh selalu ngerasa e.. dibantu, aku tuh selalu ngerasa aku gak sendirian gitu loh kerja disitu gitu, mereka tuh selalu ada ketika misalnya aku mau nanya[..]”

\section{3) Dedikasi atau rasa kepemilikan perusahaan}

Ketiga partisipan mengungkapkan perasaan ketertarikan dan keinginan untuk berkontribusi pada perusahaan. Rasa kepemilikan akan perusahaan, dedikasi akan perusahaan hingga rasa bangga terhadap pekerjaan dan perusahaannya.

Partisipan 1 mengungkapkan ingin memberikan kontribusi pada kemajuan perusahaan, kemajuan perusahaan dapat dilihat dari profit atau keuntungan yang dihasilkan hal ini juga berhubungan dengan kinerja partisipan. Partisipan 3 pun ingin membuat nilai yang baik bagi perusahaan dimata orang lain. Partisipan meyakini bahwa kesempatan belajar yang ia dapatkan di perusahaan sekarang mungkin tidak akan ia dapatkan di tempat lain walaupun ia mengungkapkan dirinya pernah merasakan stres dengan beban kerja yang ada.

"he em, kalau arti bekerja di tempat saat ini tuh pastinya memberikan kontribusi untuk kemajuan company gitu. Em kemajuan company ini pertama pasti dari em profit yang bisa dihasilkan dair kinerja kita ke company. Kemudian kemajuan itu juga berarti nilai company itu sendiri gitu sampe ke lebih banyak orang nih gitu [..]"

"[..] kalau aku kerja di tempat lain mungkin aku akan.. mungkin aku gak akan mendapatkan kesempatan aku belajar sebanyak aku belajar di X gituuu cumannn yang namanya manusia kadang suka ngerasa em.. itu yaa ketika kita lagi stres.. atau lagi sedih [...]"

Partisipan 2 mengungkapkan perasaan bangga akan kesempatan belajar yang ia dapatkan di perusahaannya. Partisipan merasa kantor sebagai rumah kedua karena partisipan merasa sebagai individu yang mudah beradaptasi. Partisipan pun merasa bangga akan kekompakkan yang dimiliki oleh tim partisipan bekerja.

"arti perusahaan ini? Sebenernya perusahaan ini bisa aku bilang juga rumah kedua juga sih, udah.. udah.. karena gak.. gak tau ya aku emang orangnya.. orang yang.. yang cenderung bisa beradaptasi alhamdulillah bisa beradaptasi dengan yang gak susah susah banget [..]"

"[..] karyawan kantor ku juga bisa dibilang rumah kedua juga karena kan tadi ya karena kompak itu [..]”

Partisipan 3 mengungkapkan pemikiran tujuan ia bekerja selain mendapatkan penghasilan juga untuk menambah ilmu, pengalaman, dan relasi. Hal ini pun bertujuan untuk memaksimalkan kinerja yang akan membantu perusahaan dalam mencapai target. Partisipan pun merasakan kenyamanan baik dengan rekan kerja dan atasan maupun fasilitas yang diberikan oleh perusahaan, partisipan menganggap kantor sebagai rumah kedua. 
"[..] bekerja menurut aku tuh selain nambah ilmu juga nambah relasi, nambah pengalaman dan juga.. terutama.. gak terutama sih mungkin salah satu pilihannya itu salah satu masuk listnya itu ya untuk mencari penghasilan juga sih kayak gitu.. tapi memang bekerja yang menurut aku e... definisi bekerja e... yang paling aku banget itu ya cari pengalaman cari ilmu gitu"

"[..] kalo sekarang mindset nya SDM, mindset ku itu lebih ke arah mindset perusahaan gimana sih perusahaan itu bisa memaksimalkan kinerjanya, otomatis kan orang orangnya juga harus di optimalisasikan kan kerjanya kayak gitu"

"[..] orang orangnya itu menganggap bahwa kantor itu rumah kedua gitu heheh jadinya tuh mereka sebisa mungkin tuh membuat diri mereka nyaman di perusahaan gitu dan atasan ku, manager ku, manager SDM ku pun juga aku cukup deket [..]"

\section{4) Kesulitan yang dihadapi}

Ketiga partisipan memiliki kesulitan dan tantangan masing-masing dalam menjalani tanggung jawab pekerjaannya.

Partisipan 1 mengungkapkan dirinya merasa stres dan sedih ketika target capaian kerja tidak terpenuhi. Keadaan yang tidak menentu karena terkadang partisipan dapat melebihi target, ada kalanya partisipan tidak dapat memenuhi target. Hal itu membuat partisipan stres walaupun tidak ada konsekuensi yang berat akan tidak terpenuhinya target tersebut tetapi partisipan merasa memiliki tanggung jawab atas hal itu.

"[..] sempet stres kemarin e.. karena gini as rekruter kita kan punya target juga ya, [..] Di rekrutmentnya itu kan targetnya tadi ya 4 sampai 5 orang kandidat sementara kalau di rekrutmen itu menurut aku tuh banyak faktor $\mathrm{X}$ itu yang membuat apa ya.. bisa... apa ya... yang membuat tuh fluktuatif banget gitu loh, setiap bulannya itu bener-bener bisa naik turun banget gitu. Jadi bisa 1 bulan tuh aku kadang bisa hire 8 orang tapi bulan selanjutnya bisa kayak cuma 1 orang gitu, itu lumayan bisa bikin stres banget sebenernya. Sampe kayak kemarin tuh beberapa kali nangis gitu gara- gara... lebih ke bingung sih gitu kayak kok targetnya gak naik naik terus [..]"

"[..] gak ada ketentuannya kalau misalkan kita gak capai target gak ada gimana gimana sih cuma kayak lebih ke tanggung jawab aja gimana kayak... iya lebih ke tanggung jawabnya gimana ya......]"

Partisipan 2 mengungkapkan kesulitan mencari calon karyawan atau kandidat yang sesuai dengan kualifikasi yang diinginkan oleh atasan sedangkan permintaan atasan terkadang selalu berubah-ubah sehingga bagi partisipan hal itu membuat pekerjaan kurang efisien.

"kesulitan... itu sih cari.. cari.. kesulitannya tetep cari kandidat ya.. tetep cari kandidat yang sesuai [..]"

"[..] kendalanya disitu bisa menemukan yang cocok dari.. yang bisa cocok dengan segitu layernya tahap interviewnya gitu"

"[..] Iya banyak permintaan dengan keribetan user gitu, keribetan di.. drama ditolak tolak user gitu, di tolak tolak user terus gitu, itu terus e... itu sih biasanya [..]”

Partisipan 3 mengungkapkan kesulitan dan tantangan yang dihadapinya antara lain adalah keletihan dan keribetan karena banyak yang harus dilakukan ketika sedang mempersiapkan training. Partisipan juga mengungkapkan kesulitan ketika rencana tidak berjalan dengan baik sesuai rencana. Pun beberapa karyawan yang kurang kooperatif menjadi sebuah tantangan dan kesulitan yang dialami karena beberapa karyawan masih menganggap bahwa training itu tidak diperlukan.

"kalauu pas lagi banyak banget trainingnya jujur capek sih ya, hectic banget disitu, karena kan ya emang aku koordinasinya emang harus ke banyak, aku ngurusin [..]"

"oh kalo kesulitan itu sebenernya... ada beberapa sih kayak pertama terkadang itu gak semua training yang aku rencana kan aku buat gitu, rencana tahunan yang aku buat itu terlaksana [..]"

"[..] kesulitannya yang kedua itu jujur di kantor ku itu banyak karyawannya yang kurang kooperatif sama SDM gitu [..]"

"[..] mindset karyawan di perusahaan aku terkait training itu mereka tuh masih belum ngerasa... kayak training itu mereka perlu gitu [..]" 


\section{5) Ketahanan}

Disamping kesulitan dan tantangan yang dihadapi oleh masing-masing partisipan. Ketiga partisipan memiliki upaya untuk dapat bertahan dan menjalani pekerjaan dengan baik. Ketiga partisipan pun mengungkapkan bagaimana cara mengatasi kesulitan dan tantangan tersebut.

Partisipan 1 mengevaluasi hasil kerja sebulan sebelumnya terkait alasan targetnya tidak tercapai. Partisipan 1 terkadang dibantu oleh rekan kerja untuk mencari solusi dari permasalahan yang ada.

"[..] kayak jadi lebih mikir lagi gitu kayak ngapain ya kemaren 1 bulan kok bisa gak dapet target gitu terus misal kayak mikir juga kemaren apa yang perlu di evaluasi dan lain-lain gitu"

"[..] Dicari solusinya pun rame-rame gitu.. itu sih itu sangat sangat meringankan sih"

"[..] iya so far untuk saat ini yaa jalani aja sebaik-baiknya gitu [..]"

"[..] tapi kalau udah achieve tuh happy nya itu happy happy banget gitu"

Partisipan 2 untuk mencapai target pekerjaan, ia memanfaatkan waktu yang tersedia disela-sela pekerjaan lain. Partisipan memiliki cara untuk mengatasi kesulitan dalam mencari kandidat yang sesuai dengan mengobservasi karyawan yang sudah lebih dulu berhasil di rekrut, bertanya langsung pada atasan suatu divisi terkait spesifikasi kompetensi yang diinginkan. Partisipan juga memiliki inisiatif untuk belajar, bertanya, dan mencari informasi yang diperlukan.

"[..] kita sambil sela selanya itu kita sambil screening, screening $C V$ gitu jadi kita punya target itu minimal banget itu $100 C V$ gitu $100 C V$ yang di screening.. [..]"

"[..] aku tanya tanya juga usernya inginnya orangnya kayak gimana sih, mulai ke supervisor mulai juga ke manager ku nanya kayak, oh ini user ini user ini orangnya kayak gimana gitu terus cenderungnya itu dia itu sukanya kayak yang kayak gimana gitu terus aku juga itu.. observasi orang-orang yang udah keterima lah udah berhasil kerjasama sama dia nih orang-orang kayak gimana sih [..]"

"[..] jadi cuman di kasih PTK ya... mau gak mau kita harus nyari tau sendiri gitu ke usernya [..]"

Partisipan 3 melakukan evaluasi diri untuk mengatasi rencana yang tidak tercapai sebelumnya dengan mengevaluasi bagian mana yang dirasa kurang baik. Partisipan pun memiliki inisiatif untuk banyak belajar untuk menunjang pekerjaan dengan mengenal karyawan.

"[..] atau mungkin bisa jadi vendornya ini sebenernya bagus gak sih, kalau misalkan kita dapet evaluasi dari mereka kan kita bisa, oh ternyata vendornya kurang bagus nih kita ganti deh tahun depan jangan pake vendor ini lagi [..]"

"[..] jadi clueless banget gitu, tapi di satu sisi aku jadi mau belajar gitu aku tuh jadi.. mau belajar, banyak belajar, jadi ya aku gak ngawang-ngawang banget [..]"

"[..] aku anggap sebagai kelebihan aku jadi juga banyak kenal karyawan otomatis kan aku juga mulai tau nih oh karyawan itu seperti ini, ada karyawan yang seperti ini, ada karyawan yang e.. ternyata agak sulit untuk di ajak kerjasama, ada karyawan yang ternyata sangat gampang untuk diajak kerjasama kayak gitu gitu sih"

Tabel 2. Temuan penelitian

\begin{tabular}{|c|c|c|c|c|}
\hline No. & $\begin{array}{c}\text { Tema } \\
\text { Superordinat }\end{array}$ & Partisipan 1 & Partisipan 2 & Partisipan 3 \\
\hline 1. & $\begin{array}{l}\text { Penilaian } \\
\text { terhadap } \\
\text { perusahaan }\end{array}$ & $\begin{array}{l}\text { Memiliki ketertarikan } \\
\text { pada perusahaan. } \\
\text { Rekan kerja yang } \\
\text { supportive. } \\
\text { Perusahaan } \\
\text { memberikan ruang } \\
\text { untuk belajar dan } \\
\text { menemukan hal-hal } \\
\text { baru, dan perusahaan } \\
\text { sebagai kesempatan } \\
\text { besar untuk }\end{array}$ & $\begin{array}{l}\text { Perusahaan sebagai } \\
\text { gerbang pembuka karir } \\
\text { dan jalan rezeki. Adanya } \\
\text { loyalitas, kekompakan } \\
\text { dan kebersamaan antar } \\
\text { karyawan. }\end{array}$ & $\begin{array}{l}\text { Lokasi perusahaan dekat } \\
\text { dari rumah sehingga terasa } \\
\text { seperti bukan tempat untuk } \\
\text { bekerja. Merasa diayomi } \\
\text { oleh rekan kerja karena } \\
\text { paling muda. Rekan kerja } \\
\text { saling bantu ketika ada } \\
\text { kesulitan dari masalah } \\
\text { pekerjaan sampai masalah } \\
\text { pribadi. }\end{array}$ \\
\hline
\end{tabular}

2. Kepuasan Kemanfaatan yang

Kemanfaatan yang

Kemanfaatan dan 


\begin{tabular}{|c|c|c|c|c|}
\hline No. & $\begin{array}{c}\text { Tema } \\
\text { Superordinat }\end{array}$ & Partisipan 1 & Partisipan 2 & Partisipan 3 \\
\hline & $\begin{array}{l}\text { terhadap } \\
\text { perusahaan } \\
\text { dan } \\
\text { lingkungan }\end{array}$ & $\begin{array}{l}\text { didapat; kebijakan } \\
\text { atasan transparan, } \\
\text { memberikan } \\
\text { kesempatan karyawan } \\
\text { untuk belajar dan } \\
\text { berkembang. }\end{array}$ & $\begin{array}{l}\text { dirasakan; mendapatkan } \\
\text { pelajaran dengan } \\
\text { learning by doing (yang } \\
\text { mungkin belum pasti } \\
\text { akan partisipan } \\
\text { dapatkan ditempat lain) } \\
\text { dan perasaan nyaman } \\
\text { karena usia rekan kerja } \\
\text { tidak berbeda terlalu } \\
\text { jauh. }\end{array}$ & $\begin{array}{l}\text { kenyamanan yang didapat; } \\
\text { rekan kerja saling } \\
\text { membantu, fasilitas kantor } \\
\text { yang nyaman. }\end{array}$ \\
\hline 3. & $\begin{array}{l}\text { Dedikasi } \\
\text { atau rasa } \\
\text { kepemilikan } \\
\text { perusahaan }\end{array}$ & $\begin{array}{l}\text { Ingin memberikan } \\
\text { kontribusi pada } \\
\text { kemajuan perusahaan. } \\
\text { Meyakini kesempatan } \\
\text { belajar yang didaptkan } \\
\text { dari perusahaan } \\
\text { mungkin tidak akan } \\
\text { didapatkan ditempat } \\
\text { lain. }\end{array}$ & $\begin{array}{l}\text { Perasaan bangga akan } \\
\text { kesempatan belajar yang } \\
\text { didapat. Perasaan } \\
\text { bangga akan } \\
\text { kekompakkan dari tim } \\
\text { kerja partisipan. }\end{array}$ & $\begin{array}{l}\text { Memaksimalkan kinerja } \\
\text { yang akan membantu } \\
\text { perusahaan dalam } \\
\text { mencapai target. Perasaan } \\
\text { nyaman dengan rekan kerja } \\
\text { dan atasan. Perusahaan } \\
\text { sebagai rumah kedua. }\end{array}$ \\
\hline 4. & $\begin{array}{l}\text { Kesulitan } \\
\text { yang } \\
\text { dihadapi }\end{array}$ & $\begin{array}{l}\text { Stres dan sedih ketika } \\
\text { target capaian tidak } \\
\text { terpenuhi. }\end{array}$ & $\begin{array}{l}\text { Kesulitan mencari } \\
\text { kadidat yang sesuai } \\
\text { dengan kualifikasi yang } \\
\text { diminta perusahaan } \\
\text { yang selalu berubah- } \\
\text { ubah. }\end{array}$ & $\begin{array}{l}\text { Keletihan atau keribetan } \\
\text { saat mempersiapkan } \\
\text { training. Ketika rencana } \\
\text { tidak berjalan dengan baik. } \\
\text { Beberapa karyawan yang } \\
\text { kurang kooperatif } \\
\text { merupakan tantangan dan } \\
\text { kesulitan. }\end{array}$ \\
\hline 5. & Ketahanan & $\begin{array}{l}\text { Mengevaluasi hasil } \\
\text { kerja bulan } \\
\text { sebelumnya dan } \\
\text { terkadang dibantu oleh } \\
\text { rekan kerja. }\end{array}$ & $\begin{array}{l}\text { Memanfaatkan waktu } \\
\text { yang tersedia disela-sela } \\
\text { perkejaan lain. Inisiatif } \\
\text { dalam menambah upaya } \\
\text { yang dilakukan untuk } \\
\text { membantu kesulitan } \\
\text { yang ada. }\end{array}$ & $\begin{array}{l}\text { Evaluasi diri dalam } \\
\text { mengatasi rencana yang } \\
\text { tidak berjalan dengan baik. } \\
\text { Memiliki inisiatif untuk } \\
\text { belajar guna menunjang } \\
\text { pekerjaan. }\end{array}$ \\
\hline
\end{tabular}

Ketiga partisipan memaknai perjalanan bekerjanya menjadi karyawan HRD dan mengatasi emosi negatif yang dialami dengan keunikannya masing- masing. Setiap partisipan dalam perjalanan kerjanya mengalami emosi negatif dan memberikan makna pada kebahagiaan di tempat kerja. Partisipan 1 memaknai kebahagiaan di tempat kerja dengan memiliki rekan kerja yang suportif, mendapatkan ruang belajar untuk mengembangkan diri, dan adannya keterbukaan akan kebijakan perusahaan. Partisipan 2 memaknai kebahagiaan di tempat kerja dengan adanya perasaan nyaman terhadap rekan kerja, kesempatan untuk mendapatkan pelajaran baru, dan adanya perasaan kebersamaan dengan rekan kerja. Partisipan 3 memaknai kebahagiaan di tempat kerja dengan tempat kerja yang sudah dianggap seperti rumah sendiri, kenyamanan fasilitas kantor dan rekan kerja yang mengayomi untuk saling membantu. Gambaran kebahagiaan di tempat kerja ketiga partisipan tersebut menimbulkan perasaan bangga akan kekompakkan tim dan menimbulkan adanya keterikatan dengan perusahaan untuk dapat berkontribusi pada tujuan dan kemajuan perusahaan.

\section{Pembahasan}

Ketiga partisipan memiliki keunikannya masing-masing dalam perjalanan tumbuh dan kembang mengatasi emosi negatif serta memberikan kemampuan terbaiknya untuk membantu dirinya mengahadapi tantangan sebagai individu yang bekerja di sebuah perusahaan. Ketiga partisipan sebagai karyawan divisi HRD memiliki persepsi yang baik terhadap perusahaannya masing-masing, hal ini 
berdampak pada gambaran kebahagiaan saat bekerja. Penilaian yang baik timbul karena adanya kepuasaan pada setiap partisipan. Partisipan merasakan keterikatan pada perusahaan, memiliki rekan kerja yang suportif, dan mendapatkan ruang untuk belajar untuk mengembangkan diri. Partisipan merasakan adanya keterkaitan dan kekompakan bersama rekan kerja serta merasa diayomi oleh rekan kerja ketika menemukan kesulitan dalam proses kerja hingga permasalahan personal. Kemudian adanya keterbukaan kebijakan perusahaan sehingga menimbulkan rasa nyaman bagi karyawan. Kepuasan karyawan tersebut menunjukkan kaitannya dengan adanya dukungan dari rekan kerja dan perusahaan sehingga merasakan keterikatan diantara karyawan. Kepuasan kerja, dukungan organisasi, dan keterikatan antar karyawan meningkatkan kebahagiaan bagi karyawan di tempat kerja (Novliadi \& Anggraini, 2020). Adanya dukungan organisasi serta keseimbangan hidup dan bekerja akan menumbuhkan kabahagiaan dan mendorong perilaku positif dalam organisasi dan memiliki hubungan negatif pada kelelahan karyawan (Khoiriyah et al., 2020; Meyers et al., 2019).

Partisipan menyampaikan kebahagiaannya dengan adanya keinginan untuk berkontribusi pada kemajuan perusahaan untuk dapat mencapai target perusahaan serta adanya anggapan perusahaan sebagai rumah kedua bagi partisipan. Keinginan kuat untuk berusaha menjadi anggota organisasi untuk mewujudkan tujuan organisasi disebut sebagai komitmen organisasi (Luthans, 2006). Pada prosesnya, karyawan mengalami keletihan, stres, dan perasaan sedih. Namun dengan adanya kebahagiaan di tempat kerja, karyawan dapat mengatasi atau dapat resilien dari emosi negatif yang dialami. Resiliensi menciptakan jalur emosi positif dan meningkatkan kepuasan hidup yang kemudian membantu karyawan untuk tetap memiliki komitmen terhadap organisasi atau perusahaannya (Paul et al., 2020; Rahmawati, 2013). Adanya komitmen organisasi pada karyawan terhadap perusahaannya dapat meningkatkan kinerja karyawan dalam perusahaan. Kebahagiaan berperan sebagai mediator dalam pengaruh komitmen organisasi terhadap kinerja karyawan (Vaseghi \& Almadlou, 2019 ). Disamping itu kebahagiaan dan komitmen organisasi meningkatkan kinerja karyawan melalui motivasi kerja karyawan (Agustien \& Drahen, 2020). Oleh karena itu, kebahagiaan di tempat kerja sangat penting bagi seluruh karyawan apalagi untuk divisi HRD yang bertugas untuk mengelola sumber daya manusia di dalam perusahaan sehingga dapat memberikan kinerjanya secara efektif dan efisien.

Happiness at work atau kebahagiaan di tempat kerja adalah konsep yang memayungi berbagai konsep seperti suasana hati dan emosi yang bersifat sementara hingga suasana hati dan emosi yang relatif stabil (Fisher, 2010). Menjadi bahagia sangat penting bagi mayoritas orang dan kebahagiaan ditemukan sebagai tujuan yang sangat dihargai oleh masyarakat (Diener, 2000). Kebahagiaan adalah sebuah dasar emosi yang dimiliki manusia. Lutterbie dan J. Pryce-Jones (2013) menjelaskan happiness at work atau kebahagiaan di tempat kerja adalah sebuah pola pikir yang memungkinkan individu untuk memberikan kinerja yang maksimal dan memaksimalkan potensial yang dimiliki. Dilakukan dengan memperhatikan suka dan duka saat bekerja sendiri atau bersama orang lain. Seperti pengalaman yang dialami ketiga partisipan, disamping adanya kesulitan dan tantangan yang dialami ketiga partisipan dapat memanfaatkan kebermanfaatan yang didapatkan dari perusahaan. Ketiga partisipan mengungkapkan bahwa ketiganya mendapatkan kesempatan yang mungkin belum tentu didapatkan jika dirinya bekerja di tempat lain. Happiness at work adalah ketika individu menikmati pekerjaannya dan menyukai apa yang sedang dilakukan bahkan disituasi yang sulit pun dapat diatasi dengan mudah (Januwarsono, 2015). Mengatasi emosi negatif dan memberikan kemampuan terbaiknya dari insight yang telah didapatkan untuk membantu dirinya sendiri adalah happiness at work (Pryce-Jones, 2010). Ketiga partisipan mengungkapkan kebermanfaatan yang didapat dari perusahaan sehingga nantinya ketiga partisipan dapat berkembang menjadi lebih baik dengan memiliki kompetensi.

Hasil analisis menunjukkan lima tema superordinat, kelima tema superordinat tersebut mewakili tiga dimensi pada konsep happiness at work yaitu; (1) penilaian terhadap perusahaan, mewakili dimensi engagement atau keterlibatan yang mewakili keterikatan emosional yang menyenangkan yang dihasilkan dari penilaian pekerjaan atau pengalaman kerja individu, (2) kepuasan terhadap perusahaan dan lingkungan, mewakili job satisfaction atau kepuasan kerja yaitu penilaian tentang pekerjaan ataupun perusahaan tempat kerja seperti aspek gaji, relasi dengan rekan kerja, relasi dengan atasan dan lingkungan kerja, (3) dedikasi atau rasa kepemilikan perusahaan, mewakili dimensi affective organizational commitment atau komitmen organisasi yaitu perasaan keterikatan, kepemilikan dan nilai cocok dengan organisasi, perilaku dimana orang mendedikasikan diri mereka pada pekerjaan, kemudian (4) kesulitan yang dihadapi, adalah hal yang pasti setiap individu alami tetapi bagaimana individu itu dapat menjalani aktivitas walaupun adanya kesulitan dan tantangan, (5) ketahanan, terkait dengan konsep happiness at work dimana individu dapat berkembang dengan mengatasi emosi 
negatif serta memberikan kemampuan terbaiknya untuk membantu dirinya saat menghadapi kesulitan dan tantangan (Pryce-Jones, 2010).

Temuan didukung oleh penelitian Prasetyo (2015) yang mengungkapkan faktor-faktor yang dapat memengaruhi kebahagiaan kerja yaitu; (1) relasi dengan orang lain, baik itu dengan keluarga maupun rekan kerja, (2) pengembangan karir atau adanya kejelasan karir beserta program pengembangan karir yang jelas, (3) keterlibatan penuh pada karir dan aktivitas lain seperti hobi dan aktivitas bersama keluarga, hal ini tidak hanya membawa kebahagiaan tetapi dapat meningkatkan sistem kekebalan tubuh, (4) penemuan makna dan keyakinan terhadap nilai-nilai yang dengan dalam keseharian. Kemudian Wulandari dan Widyastuti (2014) pada penelitiannya mengungkapkan lima faktor yang membuat individu bahagia di tempat kerja yaitu, (1) hubungan positif dengan orang lain seperti dukungan dari rekan kerja dan atasan, (2) prestasi seperti keberhasilan dalam menyelesaikan tugas, kesesuaian pekerjaan, dna mengembangkan diri, (3) lingkungan kerja fisik seperti fasilitas, (4) kompensasi seperti gaji dan insentif, (5) kesehatan. Hubungan positif dengan orang lain memiliki persentase terbesar, hal ini menunjukkan bahwa hubungan positif dengan rekan kerja adalah salah satu sumber kebahagiaan di tempat kerja (Wulandari \& Widyastuti, 2014).

Pada penelitian ini, peneliti telah berusaha semaksimal mungkin untuk memberikan hasil yang terbaik, tetapi ada keterbatasan dari proses pengumpulan data yang dilakukan secara daring menggunakan media meeting online mengingat kondisi pandemi COVID-19. Proses pengumpulan data dapat dilaksanakan dengan baik walaupun ada sedikit gangguan pada jaringan internet.

\section{Kesimpulan}

Penelitian ini mengungkap pengalaman karyawan yang bekerja di divisi $H R D$. Hasil penelitian memunculkan lima tema superordinat, yaitu (1) penilaian terhadap perusahaan, (2) kepuasan terhadap perusahaan dan lingkungan, (3) dedikasi atau rasa kepemilikan perusahaan, (4) kesulitan yang dihadapi, (5) ketahanan. Temuan penelitian ini menunjukkan setiap individu memiliki kesulitan dan tantangan yang dihadapi sebagai sebuah perjalanan tumbuh dan kembang individu yang bekerja di sebuah perusahaan. Kebahagiaan di tempat kerja adalah pola pikir cara individu dapat menjalani aktivitas walaupun terdapat kesulitan dan tantangan sehingga individu dapat berkembang dengan mengatasi emosi negatif serta memberikan kemampuan terbaik untuk membantu dirinya saat menghadapi kesulitan dan tantangan (Pryce-Jones, 2010). Perlu diingat kembali bahwa happiness at work atau kebahagiaan di tempat kerja adalah sebuah pola pikir yang memungkinkan individu untuk memberikan kinerja yang maksimal dan memaksimalkan potensial yang dimiliki (Lutterbie \& J. PryceJones, 2013). Maka hal ini penting bagi karyawan divisi HRD dapat mengatasi emosi negatif dengan menyeimbangkan faktor-faktor yang berasal dari dalam maupun luar dirinya sehingga dapat meningkatkan produktivitas serta memahami dan memiliki pola pikir tersebut sehingga dapat memaksimalkan potensi yang dimiliki untuk mengelola seluruh karyawan pada perusahaan.

\section{Daftar Pustaka}

Agustien, E., \& Drahen, P. (2020). Pengaruh organizational commitment, happiness at work, dan motivasi kerja terhadap kinerja pegawai di BKKBN. Jurnal Ilmu Administrasi Publik, 8(2).

Brocki, J. M., \& Wearden, A. J. (2006). A critical evaluation of the use of interpretative phenomenological analysis (IPA) in health psychology. Psychology and Health, 21(1), 87-108. Doi: 10.1080/14768320500230185

Carr, A. (2004). Positive psychology: The science of happiness and human strengths. New York: BrunnerRoutledge.

Diener, E. (2000). Subjective well-being. American Psychologist, 55, pp. 34-43.

Fisher, C. D. (2010). Happiness at Work. International Journal of Management Reviews, 12(4), 384-412. Doi: $10.1111 /$ j.1468-2370.2009.00270.x

Hamad, F., \& Mahidy, A. (2018). Term human resource development is combining to some HRM concept of human recourse development. September. Doi: 10.13140/RG.2.2.34328.65285

Hassan, A. (2007). Human resource development and organizational values. Journal of European Industrial Training, 31(6), 435-448. Doi: 10.1108/03090590710772631

Interactive, H. (2012, March). Workplace survey american psychological association. American Psychological Association. Retrieved from https://www.apa.org/news/press/releases/phwa/workplacesurvey.pdf 
Irmawati, A. (2015). Peran human resource development (HRD) dalam meningkatkan produktivitas karyawan. Jurnal Aplikasi Administrasi, 18(2), 123-132.

Jang, S., \& Ardichvili, A. (2020). The role of HRD in CSR and sustainability: a content analysis of corporate responsibility reports. European Journal of Training and Development. Doi: 10.1108/EJTD-01-2020-0006

Januwarsono, S. (2015). Analytical of Factors Determinants of Happiness at Work: Case Study on PT. PLN (Persero) Region Suluttenggo, Sulawesi, Indonesia. European Journal of Business and Management, 78), 9-18.

Joo, B. K., \& Lee, I. (2017). Workplace happiness: work engagement, career satisfaction, and subjective well-being. Evidence-Based HRM, 5(2), 206-221. Doi: 10.1108/EBHRM-04-2015-0011

Kasmawati, Y. (2017). Human capital dan kinerja karyawan (suatu tinjauan teoritis). JABE (Journal of Applied Business and Economic), 3(4), 265-280. Doi: 10.30998/jabe.v3i4.1781

Keyes, C. L. M., Hysom, S. J., \& Lupo, K. L. (2000). The positive organization: Leadership legitimacy, employee well-being, and the bottom line. The Psychologist-Manager Journal, 4(2), 143-153. Doi: 10.1037/h0095888

Khoiriyah, D., Diah Sari, E. Y., \& Widiana, H. S. (2020). Keterikatan Kerja Perawat: Pengaruh Dukungan Organisasi, Work-Life Balance Dan Kebahagiaan. PSYCHE: Jurnal Psikologi, 2(1), 4051. Doi: $10.36269 /$ psyche.v2i1.179

Luthans, Fred. (2006). Perilaku organisasi. Yogyakarta: Andi (alih bahasa oleh Vivi Andhija Yuwono).

Lutterbie, S., \& J. Pryce-Jones. (2013). Measuring Happiness at Work: BPS - iOpener Institute. https://iopenerinstitute.com/measuring-happiness-work-bps/

Meyers, M. C., Adams, B. G., Sekaja, L., Buzea, C., Cazan, A. M., Gotea, M., Stefenel, D., \& van Woerkom, M. (2019). Perceived Organizational Support for the Use of Employees' Strengths and Employee Well-Being: A Cross-Country Comparison. Journal of Happiness Studies, 20(6), 18251841. Doi: 10.1007/s10902-018-0026-8

Novliadi, F., \& Anggraini, R. (2020). Happiness at Work Viewed from Job Satisfaction and Perceived Organizational Support. ICOSTEERR 2018 - International Conference of Science, Technology, Engineering, Environmental and Ramification Researches, 7, 1815-1820. Doi: $10.5220 / 0010102318151820$

Matthews, B., \& Ross, L. (2010). Research methods: A practical guide for the social sciences. New York: Pearson.

Oswald, A. J., Proto, E., \& Sgroi, D. (2015). Happiness and productivity. Journal of Labor Economics, 33(4), 789-822. Doi: 10.1086/681096

Parameswari, B. N., \& Yugandhar, V. (2015). The role of human resource management in organizations. Inte Rnational Journal of Engineering Technology, 3(7), 58-62. http://www.ijetmas.com/admin/resources/project/paper/f201507151436938950.pdf

Park, S., Jeong, S., \& Chai, D. S. (2021). Remote e-workers' psychological well-being and career development in the era of COVID-19: challenges, success factors, and the roles of HRD Professionals. Advances in Developing Human Resources, 23(3), 222-236. Doi: $10.1177 / 15234223211017849$

Paul, H., Budhwar, P., \& Bamel, U. (2020). Linking resilience and organizational commitment: does happiness matter? Journal of Organizational Effectiveness: People and Performance, 71), 21-37. Doi: 10.1108/JOEPP-11-2018-0087

Prasetyo, A. R. (2015). Gambaran Career Happiness Plan Pada Dosen. Jurnal Psikologi Undip, 14(2), 174-182. Doi: 10.14710/jpu.14.2.174-182

Pryce-Jones, J. (2010). Happiness at work: maximizing your psychological capital for success. West Sussex: John Wiley \& Sons Ltd. Doi: 10.1108/00251741111143676

Putri, N. K. (2013). Peran human capital terhadap kesuksesan organisasi: karyawan adalah investasi. Jurnal Administrasi Dan Kebijakan Kesehatan, 11(2), 93-97.

Ramadhani, D., \& Etikariena, A. (2018). Tuntutan Kerja dan Stres Kerja pada Karyawan Swasta: Peran Mediasi Motivasi Kerja. INQUIRY Jurnal Ilmiah Psikologi, g(2), 110-124.

Reid, K., Flowers, P., \& Larkin, M. (2005). Exploring lived experience. Psychologist, 18(1), 20-23.

Robbins, P. Stephen. (2006). Perilaku organisasi (edisi Bahasa Indonesia). Jakarta: PT Indeks Kelompok Gramedia.

Schaufeli, W. B., \& Bakker, A. B. (2004). Job demands, job resources, and their relationship with burnout and engagement: A multi-sample study. Journal of Organizational Behavior, 25(3), 293-315. Doi: 
10.1002/job.248

Sharma, D. (2012). New roles for HR professionals. Integral Review - A Journal of Management, 5(2), 111.

Smith, J. A., P. Flower \& M. Larkin. (2009). Interpretative phenomenological analysis: theory, method and research. London: Sage.

Swanson, Richard A., \& Holton Elwood F. (2001). Foundations of human resource development: first edition. San Franscisco: Berrett- Koehler Publishers, Inc.

The National Institute for Occupational Safety and Health (NIOSH). (1999). Stress at Work. Ditemu kembali dari https://doi.org/10.26616/NIOSHPUB99101 Diakses 1 Februari 2021

Vaseghi, A., \& Almadlou, M. (2019). Investigating the effect of organizational commitment on the employee performance with the mediating role of organizational pappiness. Journal of Career Studies, 2(9-24).

Wulandari, S., \& Widyastuti, A. (2014). Faktor - faktor kebahagiaan di tempat kerja. Jurnal Psikologi UIN Sultan Syarif Kasim Riau, 10(Juni), 41-52.

Yardley, L. (2017). Demonstrating the validity of qualitative research. Journal of Positive Psychology, 12(3), 295-296. Doi: 10.1080/17439760.2016.1262624. 